\title{
Henri Gourdin, Léopoldine. L'enfant-muse de Victor Hugo. Biographie
}

\section{Mariana Perisanu}

\section{Q OpenEdition}

10 Journals

\section{Édition électronique}

URL : http://journals.openedition.org/studifrancesi/7636

DOI : 10.4000/studifrancesi.7636

ISSN : 2421-5856

Éditeur

Rosenberg \& Sellier

\section{Édition imprimée}

Date de publication : 1 décembre 2009

Pagination : 648-649

ISSN : 0039-2944

\section{Référence électronique}

Mariana Perisanu, «Henri Gourdin, Léopoldine. L'enfant-muse de Victor Hugo. Biographie », Studi Francesi [En ligne], 159 (LIII | III) | 2009, mis en ligne le 30 novembre 2015, consulté le 09 janvier 2021. URL: http://journals.openedition.org/studifrancesi/7636 ; DOI : https://doi.org/10.4000/studifrancesi.7636

Ce document a été généré automatiquement le 9 janvier 2021.

\section{(c) $(1) \&$}

Studi Francesi è distribuita con Licenza Creative Commons Attribuzione - Non commerciale - Non opere derivate 4.0 Internazionale. 


\title{
Henri Gourdin, Léopoldine. L'enfant- muse de Victor Hugo. Biographie
}

\author{
Mariana Perisanu
}

\section{RÉFÉRENCE}

HENRI GOURDIN, Léopoldine. L'enfant-muse de Victor Hugo. Biographie, Paris, Presses de la Renaissance, 2007, pp. 300.

1 Après Adèle, l'autre fille de Victor Hugo (Ramsay, 2003) et trois années d'enquête minutieuse, Henri Gourdin publie la première biographie de la fille aînée de Victor Hugo, inspiratrice de Demain dès l'aube et des Contemplations.

2 La biographie ne pouvait commencer que par la fin, la noyade tragique dans la Seine de Léopoldine (à 19 ans) et de son époux Charles Vacquerie, le 4 septembre 1843. La part de vérité et de légende est scrupuleusement analysée par l'auteur qui dévoile ses sources (p.240) et déplore les infractions aux règles élémentaires de navigation. Il insiste sur l'énorme imprudence consentie par Léopoldine qui, malgré les avertissements, a obstinément refusé de faire le trajet de Caudebec à Villequier en voiture. Son père qui apprend la nouvelle en lisant la presse, ne se remettra jamais de la disparition de sa fille bien-aimée. À part cette anticipation incontournable, les chapitres suivent l'ordre chronologique des événements et leurs titres sont souvent des citations significatives des lettres ou des œuvres hugoliennes: «N'oublie pas ta petite fille», "C'était un esprit avant d'être une femme», "Je suis heureuse, entends-tu maman», «Je voudrais ne jamais te quitter». Léopoldine (1824-1843), née une année après la mort de son frère Léopold (âgé de trois mois), fut «l'ange oublié chez moi par la pitié de Dieu» (Le Roi s'amuse), ange consolateur aussi, appelé à réparer par sa pureté virginale les faiblesses de ses parents.

3 Ce livre émouvant est en même temps une plongée au cœur de la famille Hugo. Heureux en ménage, Victor Hugo connaissait comme poète un début de notoriété et la petite Didine a eu une enfance et une adolescence heureuses. Le bébé nourri au lait de 
sa jeune mère voyageait avec ses parents à Blois, Chambord, Reims, puis dans les Alpes, accompagnés par Charles Nodier et sa famille en passant chez Lamartine à Mâcon. Fée du logis, Léopoldine goûtait les macaronis de Mérimée, causait poésie avec Vigny, voyages avec Gautier, musique avec Marmontel (son professeur de piano et celui de Bizet); elle se mettait au piano avec Liszt, tentant de répondre à l'idéal d'excellence que son entourage lui imposait. Pure, soumise, résignée, respectueuse des volontés du père, elle est l'ange sous toutes ses formes et son rôle sublime est de transmettre la prière d'Olympio. «Je suis fière de toi [cher] papa, ton nom que je porte me fait l'effet d'une couronne [...] Aime-moi et écris-moi, tu me feras un plaisir énorme, mon père adoré» (p. 132).

4 Le livre d'Henri Gourdin dévoile, avec l'intimité de cette famille célèbre, les mécanismes psychologiques et affectifs existants entre le poète olympien et sa fille qui a tant influencé l'œuvre. L'amour de Léopoldine pour Charles Vacquerie n'a pas été du goût du père qui accepte difficilement et bien tard leur union. Comme Jean Valjean qui sentait que Cosette lui échappait. «Fidèle à elle-même, Léopoldine cherche toujours, désespérément, à concilier l'inconciliable, à faire le bonheur de Victor Hugo et celui de Charles, à satisfaire famille et belle-famille. [...] Elle voulait être parfaite» (p. 211).

Les notes nombreuses et systématisées apportent des informations intéressantes sur Sainte-Beuve, Juliette Drouet, David d'Angers, sur les usages et mentalités de l'époque: le regard sur l'enfant, l'émancipation de la femme, la métempsycose, les tables tournantes de Jersey, le mobilier, la robe de mariage, la Place Royale, la première d'Angélo, tyran de Padoue et celle des Burgraves. La correspondance personnelle de Léopoldine avec Louise Bertin et Julie Foucher (mine d'or pour le biographe), ses petites colères sous les apparences du respect et de la soumission, son mariage furent pourtant des défis à son père et l'auteur suggère même que la promenade fatale sur la Seine aurait pu être un acte de désespoir car, après le mariage de sa fille, Hugo se comportait comme si elle n'existait plus.

Le biographe des deux filles Hugo peut conclure: «La gageure de Léopoldine et d'Adèle a été la même: se construire face à un père d'une stature écrasante, enclin à plier son entourage aux contraintes de sa carrière et de son équilibre affectif» (p. 115). 